\title{
The Influence of Shallot Price Fluctuations on the Improvement of Farmers' Welfare in Pekalobean Village, Anggeraja District, Enrekang Regency
}

\author{
Hermawaty Remba Kasim, Citra Ella Atmisari, Mochtar Lutfi \\ Universitas Islam Makassar \\ E-mail: hermawatyrk@gmail.com
}

(Received: February-2019; Reviewed: April-2019; Accepted: June-2019;

Avalaibel Online: August 2019; Published: September-2019)

This is an open access article distributed under the Creative Commons Attribution License CC-BY-NC-4.0 C2019 by author (https://creativecommons.org/licenses/by-nc/4.0/)

\begin{abstract}
The purpose of this study was to determine the Effect of Shallot Price Fluctuations on Farmers' Welfare Improvement in Pekalobean Village, Anggeraja District, Enrekang Regency. This type of research is quantitative with a simple linear regression analysis. The research data were obtained from the results of distributing questionnaires to shallot farmers in Pekalobean Village, Anggeraja District, Enrekang Regency, as many as 50 respondents. The results of this study indicate that the fluctuations in the price of shallots affect the welfare of farmers in Pekalobean Village Anggeraja District Enrekang Regency by $12 \%$ with a tcount of 2.520 greater than the table of 2.010 with a significance of 0.015 less than 0.05 .
\end{abstract}

Keywords: Shallot Price Fluctuations; Farmers' Welfare; Fluctuations

\section{INTRODUCTION}

Indonesia is an agricultural country, meaning that the agricultural sector plays a very important role in the national development order (Durand \& Fournier, 2017; Gollin, 2010; Telfer \& Wall, 2000; Timmer, 2005). The role given by the agricultural sector includes providing food for the entire population, contributing to the country's foreign exchange from the non-oil and gas sector, opening employment opportunities. The large population that still depends on this sector shows that in the future this sector still needs to be improved (MohamedYasseen et al., 1994). An important commodity for most Indonesian household economies that is always experiencing fluctuations in the price of shallots (Kim et al., 2017; Suharsono \& Candra, 2013).

Shallots are one of the important horticultural commodities for the people of Indonesia. This commodity has many uses, especially in the household consumption sector, among others, as a spice in cooking to add to the taste of cuisine, supplementary ingredients for food and medicines for certain diseases, so that this commodity can already be classified as one of the 
main staples given its role (Samsir et al., 2017). At present consumption of shallots tends to increase along with population growth, increasing variety of dishes using shallots, increasing public awareness of the value of nutrition, and the development of the processing industry.

Agricultural products are generally characterized by the nature of seasonal production, always fresh, perishable, large in number but relatively small in value, and local and specific (cannot be produced in all places) (Selfa \& Qazi, 2005). Agricultural products that are seasonal because they are influenced by climate. At the time of harvest, the amount of production will be large and during the lean season the amount of production is small and even the quality is not good (Shukla \& Jharkharia, 2013). This will cause the price of agricultural products to be marketed up and down (fluctuate) from year to year depending on how much the harvest last year, how much inventory is left over from the previous year and how harvest expectations for the current year.

In general the condition of national food prices tends to fluctuate and rise every year. Price fluctuations are due to an increase in demand ahead of the prices of religious and national holidays (HBKN) such as Eid al-Fitr, Eid al-Adha and Christmas, as well as the impact of price increases on international markets. Government policies such as rising fuel prices also affect price instability. For example, in the middle of 2012 there was an increase in fuel prices just before the fasting month. This has an impact on increasing the price of food for almost all commodities, especially chili, shallots, and beef which is causing turmoil in the community.

Meanwhile, Deputy of Statistics for Distribution and Services Statistics BPS said that to reduce the rate of inflation this year, it would become a homework for the government to maintain food availability. Because, commodities that are quite sensitive, such as red chili and shallots, which are only available in certain months need to be maintained so as not to experience price fluctuations.

Shallots are a commodity that has relatively high fluctuations. Fluctuations in onion prices can be caused by planting costs, weather, stock, transportation, and imported onions. Increasing demand will affect prices. In order to meet demand, the government should be able to maintain its availability. Stagnant supply to the region will result in the depletion of existing stock in the market and make the price of shallots go up. The smooth delivery of shallots from the center to areas affected by transportation costs and the weather. The issue of rising fuel prices affects consumers who will hoard staples and hinder shipping due to additional shipping costs, while extreme weather will hamper distribution, for example, shipping from outside the island which has to send goods by sea.

The regulation of production and distribution and marketing of domestic shallots is very important. The main purpose of the regulation of production and distribution is that the onion harvest can be arranged in such a way that there will be no excess or lack of onion supply. Thus the price of shallots on the retail market is relatively more stable and does not fall very low.

One of the livelihoods of the people of Pekalobean Village, Anggeraja District, Enrekang Regency is onion farming. An increase or decrease in the price of shallots will affect the economic conditions in them.

\section{METHOD}

The researcher uses the type of quantitative research, the analytical method used in this study is a descriptive method based on the title created using the Questionnaire method (J. w. Creswell, 2014). which is a written question used to obtain information from the respondent in terms of his personality or things he knows, and to make it easier to do research. The data source in this study is the subject where data can be obtained. In this study the source of the data is the residents of Pekalobean Village, Anggeraja District, Enrekang Regency who work as farmers and buyers at the time of the study. 
Data collection techniques are an important factor, because calculations are obtained from data obtained in research. Data collection methods used in this study are: 1) Questionnaire, and 2) Documentation. The sampling technique in this study uses a simple random sampling technique, namely sampling by random without regard to strata in the population, so that each element of the population has the same opportunity to be elected as a sample member to be investigated and this method is done if the population is considered homogeneous (J. W. Creswell \& Clark, 2017). The sample size is 50, the respondents are farmers and buyers of shallots in Pekalobean Village, Anggeraja District, Enrekang Regency.

Data analysis technique is a method used to process research results in order to obtain an instrument and conclusions. The analysis technique used is simple linear regression analysis. Simple linear regression analysis is a linear relationship between one independent variable (X) and the dependent variable (Y). This analysis is to determine the direction of the relationship between the independent variable with the dependent variable whether positive or negative and to predict the value of the dependent variable if it has increased or decreased. Simple linear analysis is used to determine the relationship between dependent variables, namely between Shallot Price Fluctuations (X) and Farmer's Welfare Improvement (Y).

\section{RESULT AND DISCUSSION}

The stringency of simple linear analysis is to measure the effect of independent variables on the dependent variable and predict the dependent variable using the independent variable (Sarwono, 2010).

Table 1. Summary Model

Model Summary

\begin{tabular}{lrrrr}
\hline Model & R & R Square & $\begin{array}{c}\text { Adjusted R } \\
\text { Square }\end{array}$ & $\begin{array}{l}\text { Std. Error of } \\
\text { the Estimate }\end{array}$ \\
\hline 1 & $.342^{\mathrm{a}}$ & .117 & .098 & 5.28205 \\
\hline
\end{tabular}

Sumber: Data Processed (2018)

Based on table 1, it is obtained the value of $\mathrm{R}$ Square or Determination Coefficient which shows how good the regression model is formed by the interaction of the independent variable and the dependent variable. The coefficient of determination obtained is $11.7 \%$. So it can be interpreted that fluctuations in the price of shallots have a contribution of $11.7 \%$ to the increase in the welfare of farmers in the Pekalobean Village, Anggeraja District, Enrekang Regency.

Table 2. Simple Regression Coefficient

\section{Coefficients $^{\mathrm{a}}$}

\begin{tabular}{|c|c|c|c|c|c|c|}
\hline \multirow{2}{*}{\multicolumn{2}{|c|}{ Model }} & \multicolumn{2}{|c|}{$\begin{array}{l}\text { Unstandardized } \\
\text { Coefficients }\end{array}$} & \multirow{2}{*}{$\begin{array}{c}\begin{array}{c}\text { Standardized } \\
\text { Coefficients }\end{array} \\
\text { Beta }\end{array}$} & \multirow[b]{2}{*}{$\mathbf{t}$} & \multirow[b]{2}{*}{ Sig. } \\
\hline & & B & Std. Error & & & \\
\hline \multirow[t]{2}{*}{1} & (Constant) & 15.013 & 11.343 & & 1.324 & .192 \\
\hline & Price Fluktuasi & .609 & .242 & .342 & 2.520 & .015 \\
\hline
\end{tabular}

Sumber: Data Processed (2018)

The basis for decision making in regression analysis by looking at the significant values (Sig.) In the above table are: 
a. If the significant value is smaller than the probability of 0.05 , it means that there is an influence of fluctuations in the price of shallots on improving the welfare of farmers in Pekalobean Village, Anggeraja District, Enrekang Regency.

b. Conversely, if the significant value is greater than the probability of 0.05 , it means that there is no effect of the onion price fluctuations on improving the welfare of farmers in Pekalobean Village, Anggeraja District, Enrekang Regency.

Based on the table, it is known that a significant value of 0.015 is smaller than the probability of 0.05 , so it can be concluded that there is an influence of onion price fluctuations on improving the welfare of farmers in Pekalobean Village, Anggeraja District, Enrekang Regency.

\section{Discussion}

Based on the results of the analysis that has been done, it is obtained simple linear regression test results with a significant value of 0.015 less than the probability of 0.05 so that it can be concluded that there is an influence of onion price fluctuations on improving the welfare of farmers in Pekalobean Village, Anggeraja District, Enrekang Regency. With an R square value or a Determination Coefficient of $11.7 \%$ (rounded up to $12 \%$ ) or $12 \%$, which means that fluctuations in the price of shallots have a $12 \%$ effect on improving the welfare of farmers in Pekalobean Village, Anggeraja District, Enrekang Regency. While the remaining $88 \%$ is influenced by other factors not examined by researchers such as personality factors, social factors, environmental factors and individual condition factors.

From the results of the partial test analysis (t test), the tcount value of 2.520 is greater than the ttable value of 2.010, it can be concluded that there is an influence of fluctuations in the price of shallots on improving the welfare of farmers in Pekalobean Village, Anggeraja District, Enrekang Regency.

\section{CONCLUSION}

From the simple linear regression test, it was obtained a significant value of 0.015 less than the probability of 0.05 so that it can be concluded that there is an influence of onion price fluctuations on improving the welfare of farmers in Pekalobean Village, Anggeraja District, Enrekang Regency. With an R square value or a Determination Coefficient of $11.7 \%$ (rounded up to $12 \%$ ) or $12 \%$, which means that fluctuations in the price of shallots have a $12 \%$ effect on improving the welfare of farmers in Pekalobean Village, Anggeraja District, Enrekang Regency. While the remaining $88 \%$ is influenced by other factors not examined by researchers such as personality factors, social factors, environmental factors and individual condition factors.

\section{REFERENCES}

Creswell, J. w. (2014). Research Design: qualitative, quantitative, and Mix Methods Approaches (Fourth). Sage Publications.

Creswell, J. W., \& Clark, V. L. P. (2017). Designing and conducting mixed methods research. Sage publications.

Durand, C., \& Fournier, S. (2017). Can geographical indications modernize Indonesian and Vietnamese agriculture? Analyzing the role of national and local governments and producers' strategies. World Development, 98, 93-104. 
Gollin, D. (2010). Agricultural productivity and economic growth. Handbook of Agricultural Economics, 4, 3825-3866.

Kim, J., Cha, M., \& Lee, J. G. (2017). Nowcasting commodity prices using social media. PeerJ Computer Science, 3, e126.

Mohamed-Yasseen, Y., Splittstoesser, W. E., \& Litz, R. E. (1994). In vitro shoot proliferation and production of sets from garlic and shallot. Plant Cell, Tissue and Organ Culture, $36(2), 243-247$.

Samsir, A., Ma'ruf, M. I., \& Salam, R. (2017). Impact of Income on Households Patterns of Consumption of Street Vendors in Makassar City. 8th International Conference of Asian Association of Indigenous and Cultural Psychology (ICAAIP 2017).

Selfa, T., \& Qazi, J. (2005). Place, taste, or face-to-face? Understanding producer-consumer networks in "local" food systems in Washington State. Agriculture and Human Values, 22(4), 451.

Shukla, M., \& Jharkharia, S. (2013). Agri-fresh produce supply chain management: a state-of-the-art literature review. International Journal of Operations \& Production Management.

Suharsono, J., \& Candra, S. (2013). Murabaha in Sharia Added Value, an Effort to Increase Probolinggo Shallot Farmers' Economic Scale and Spirituality. Available at SSRN 2596062.

Telfer, D. J., \& Wall, G. (2000). Strengthening backward economic linkages: Local food purchasing by three Indonesian hotels. Tourism Geographies, 2(4), 421-447.

Timmer, P. (2005). Agriculture and pro-poor growth: an Asian perspective. Available at SSRN 1114155. 
Volume 3, Issue 1, September, 2019. Pages 7-12 